\title{
Lasiothyris luminosa (Razowski \& Becker) (Lepidoptera: Tortricidae): a New Grapevine Pest in Northeastern Brazil
}

\author{
TC Costa-Lima ${ }^{1}$, GrP Moreira ${ }^{2}$, GL Gonçalves ${ }^{3,4}$, A SPeChT $^{5}$ \\ ${ }^{1}$ Brazilian Agricultural Research Corporation-Embrapa Tropical Semi-Arid, Petrolina, PE, Brasil \\ ${ }^{2}$ Depto de Zoologia, Instituto de Biociências, Univ Federal do Rio Grande do Sul, Porto Alegre, RS, Brasil \\ ${ }^{3}$ Genetics Dept, Federal Univ of Rio Grande do Sul-UFRGS, Porto Alegre, RS, Brasil \\ ${ }^{4}$ Instituto de Alta Investigación, Univ de Tarapacá-UTA, Arica, Chile \\ ${ }^{5}$ Brazilian Agricultural Research Corporation-Embrapa Cerrrados, Planaltina, DF, Brasil
}

\section{Keywords}

American grapevine moth, Neotropical region

\section{Correspondence}

GRP Moreira, Depto de Zoologia, Instituto de Biociências, Univ Federal do Rio Grande do Sul, Avenida Bento Gonçalves, 9500, 91501-910 Porto Alegre, RS, Brasil; gilson. moreira@ufrgs.br

Edited by Roberto A Zucchi - ESALQ/USP

Received 22 January 2016 and accepted 10 February 2016

Published online: 8 March 2016

(C) Sociedade Entomológica do Brasil 2016

\begin{abstract}
The little-known Neotropical tortricid moth Lasiothyris luminosa (Razowski \& Becker) is reported for the first time as a grapevine pest in northeastern Brazil. A diagnosis based on morphological characters including the genitalia is provided for both sexes, together with a preliminary description of economic damage caused by the larval stage on flowers and fruits. In addition, we sequenced a partial region of the cytochrome oxidase subunit I gene from specimens from the region and reconstructed phylogenetic relationships using representative lineages of closely related tortricids as terminals.
\end{abstract}

The low-mid São Francisco Valley (SFV) in the northeastern region is the major tropical fruit-producing area in Brazil. Grapes are a major crop in this area, and over $99 \%$ of the Brazilian table grape exports come from the SFV (Bustamante 2009). The SFV is also the second largest Brazilian wine-producing region. In June 2015, a SFV table grape producer reported larvae causing extensive damage to the flowers and grape berries on his farm. The genitalia of males reared in the laboratory from these larvae conform to Lasiothyris luminosa (Razowski \& Becker) (Lepidoptera, Tortricidae). Here, we provide the corresponding taxonomic diagnosis based on morphological characters at the genitalia level for both sexes, including the first description of the female. The pest status of Lasiothyris luminosa is reported for the first time, together with a preliminary description of damage caused by the larval stage. In addition, we sequenced a partial region of the cytochrome oxidase subunit I gene from specimens from the SFV and reconstructed phylogenetic relationships using representative, closely related lineages of tortricids as terminals (Regier et al 2012). Procedures used during molecular analyses and accession numbers for corresponding DNA sequences that were deposited in databases are provided in Supplementary Material 1. A detailed description of the integumentary morphology of the immature stages was carried out in complement at the scanning electron microscopy level and will be published elsewhere.

From June to November 2015, 15 grape-producing areas were visited in the SFV, including Lagoa Grande and Petrolina, state of Pernambuco, and Casa Nova and Juazeiro municipalities in the state of Bahia, Brazil. The overall economic damage caused in one of these farms was circa $10 \%$, which is equivalent to $U \$ 5150 / h a$. Signs of insect damage were observed in inflorescences and fruits in different stages of maturation. These plant structures were brought to the entomology laboratory of Embrapa Semi-Arid (Petrolina), isolated in plastic containers covered with a fine mesh, and maintained in a climate-controlled room $\left(25 \pm 2^{\circ} \mathrm{C}, 50 \pm 20 \%\right.$ 
$\mathrm{RH}$ and 12-h photophase). The plant structures were inspected under a stereomicroscope for the presence of eggs, larvae, or pupae of L. luminosa. The specimens $(n=16)$ were reared to the adult stage, and then either pinned and dried or fixed in Dietrich's fluid and preserved in $70 \%$ ethanol for morphological studies, as were the immature stages. Additional individuals $(n=20)$ were preserved in $95 \%$ ethanol at $-20^{\circ} \mathrm{C}$ for DNA extraction. Voucher specimens are listed in Supplementary Material 2.

For observations of the gross morphology, adults were first cleared in $10 \% \mathrm{KOH}$, dissected, dehydrated in an ethanol series, and then slide-mounted in Canada balsam, under a Leica M125 stereomicroscope. Prior to mounting, genitalia were stained with either Chlorazol Black E or eosin. Observations were performed using an Olympus BX51 microscope, where the selected genital structures were photographed with a MicroPublisher 3.3 RTV-QImaging digital camera.

This little-known tortricid moth was originally described by Razowski \& Becker (1983) as Saphenista luminosa (Razowski \& Becker), based on males collected in Brusque municipality, state of Santa Catarina, Brazil. Later, Razowski \& Becker (1993) transferred this species to the genus Lasiothyris Meyrick. As stated by these authors, species belonging to this genus are differentiated from other tortricids by the presence of a costal fold on the hind wings, abdominal scent organs on the sixth abdominal sternum of the male (Fig $1 \mathrm{~b}$ ), and a very large aedeagus (Fig 1e). Lasiothyris luminosa is a small-sized moth (forewing length: males, 3.51-4.16 mm, $n=5$; females, 3.12-4.68 mm, $n=6$ ), having a yellowish-cream ground color with a light pinkish hue, apparently similar in both sexes. The hind wing color pattern (Fig 1a) is similar to congeneric species, with black scales of the median fascia and the subterminal pattern varying in number and arrangement. The hind wings are pale brownish gray with similar fringes. As described by Razowski \& Becker (1993), males of L. luminosa in particular differ from those of its most similar species $L$. gravida Razowski, which was described from Mexico, in having larger and broader socii with a short, non-concave base. Also, in having the vinculum arms coalesced ventrally (separate in L. gravida) and in the longer aedeagus, with the cornutus of similar length (Fig 1e), among other characters. Female genitalia (Fig 1d), however, are similar to other congeneric species such as L. ilingocornuta and L. megapenis (Razowski \& Becker 1993), in having a bursa and an accessory bursa with no signum and partial sclerotization of the corresponding ducti, and the ductus seminalis opening proximally on the ductus bursae, before the opening of the accessory bursa.
Fig 1 Adult morphology of Lasiothyris luminosa: A Spread right wings of pinned and dried female. B Bifurcated scent organs on distal margin of sixth abdominal sternum of male, ventral view. C Socci of male genitalia in detail, posterolateral view (indicated by open arrow in E). D Female genitalia (roman numerals indicate bursa and accessory bursa, respectively; open arrow indicates ductus seminalis). E Male genitalia, ventral view, with long cornutus visible by transparency inside aedeagus (indicated by asterisk); open and closed arrows indicate socci and coalescent portions of vincula, respectively. Scale bars $=1 \mathrm{~mm}, 100,100,200$, and $200 \mu \mathrm{m}$, respectively.
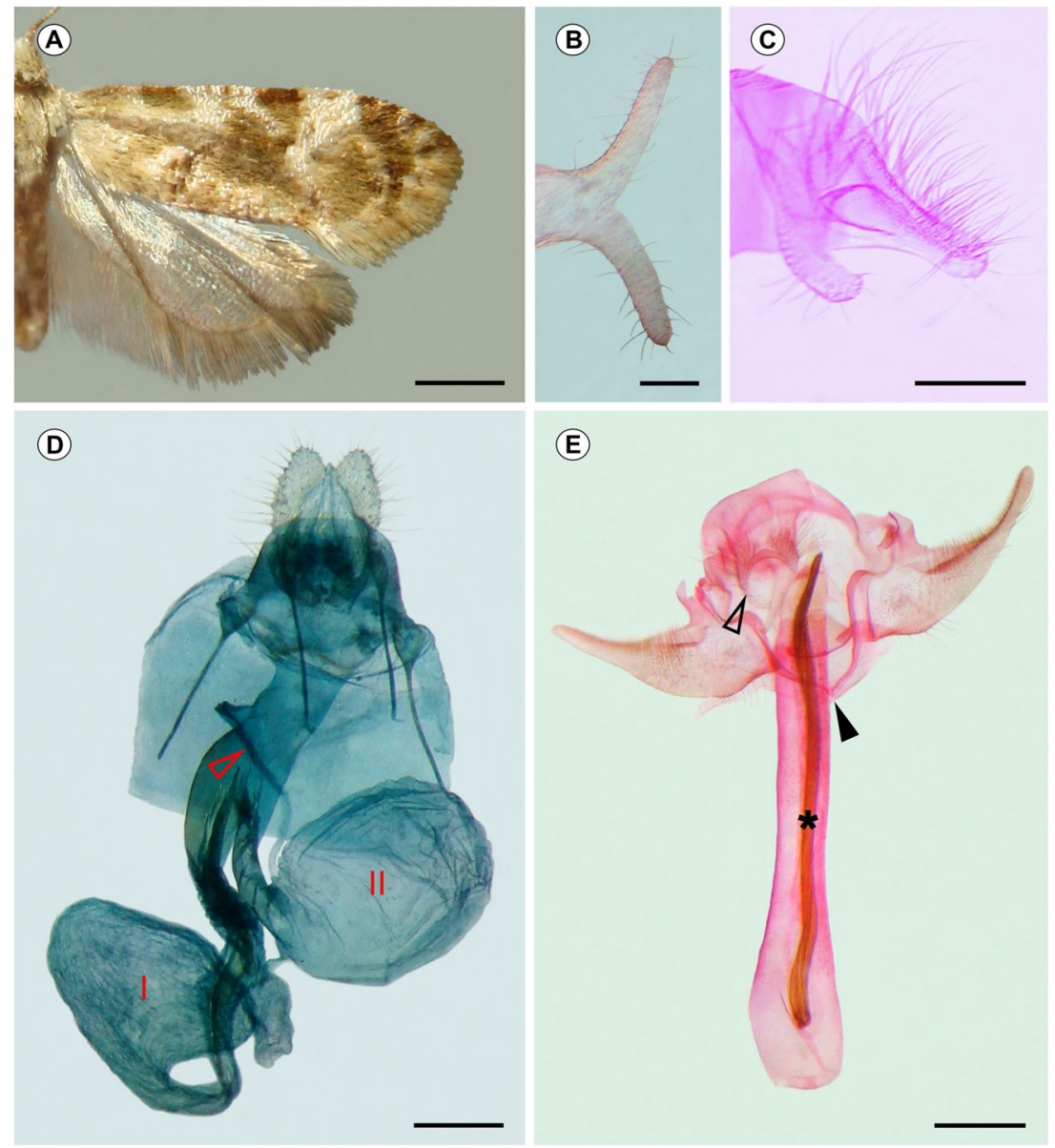
DNA sequence analysis also supported the monophyletic status of specimens collected from different inflorescence structures (Fig 2). Lasiothyris luminosa is closely related to unidentified tortricid moths, particularly the specimen BLPDT1840-10, collected in Costa Rica and deposited in the BOLD System under the project title BioLep_2011_o2 (BLPDZ). The clade formed by $L$. luminosa and these unidentified moths is sister to Aethes Billberg (species surveyed: A. smeathmanniana Fabricius), from which it diverged by circa $12 \%$. Up to now, 27 species have been assigned to Lasiothyris Meyrick, ranging in distribution from Mexico to Rio Grande do Sul, the southernmost state of Brazil (Gilligan et al 2014). They are known only from the adults, and as far as we are aware, none has been explored from a molecular-biology perspective.

The larvae attacked flowers, berries, and to a lesser degree the inflorescence stalks. In the last case, when attacked at the base, the entire inflorescence withered. Initial attacks on inflorescences occur in the flower buds, before anthesis (Fig 3b), into which early instars are capable of penetrating and feeding in the interior of the bud. After anthesis, later developing larvae may draw several flowers together that are entangled with each other by silk threads (Fig 3a), and the larvae then feed inside this clump on different structures of the inflorescence, for example on the flower pistil (Fig 3c). Lasiothyris luminosa larvae were found feeding inside the grapes themselves, at all maturation stages, from recently formed berries to those ready to harvest. Berries in the mid-ripening stage were commonly found attached to each other by silk threads (Fig 3d). In such cases, the larva may finish feeding in one grape and then move to the other, continuing internal feeding in the contiguous grape (Fig $3 \mathrm{f}$ ). The highest infestation rate was found during the maturation phase, where rotten berries (Fig 3e) could be observed in the bunches. Isolated eggs were found on the inflorescence rachis and peduncle, on flower buds, and on berries. Pupae were found protected by silk thread, either inside the berries or outside on the peduncle covered by flower parts remaining from feeding.

Lasiothyris luminosa larval feeding behavior is similar to the European grapevine moth Lobesia botrana (Denis \& Schiffermüller) (Lepidoptera, Tortricidae). This tortricid moth is one of the major grape pests in the Palearctic

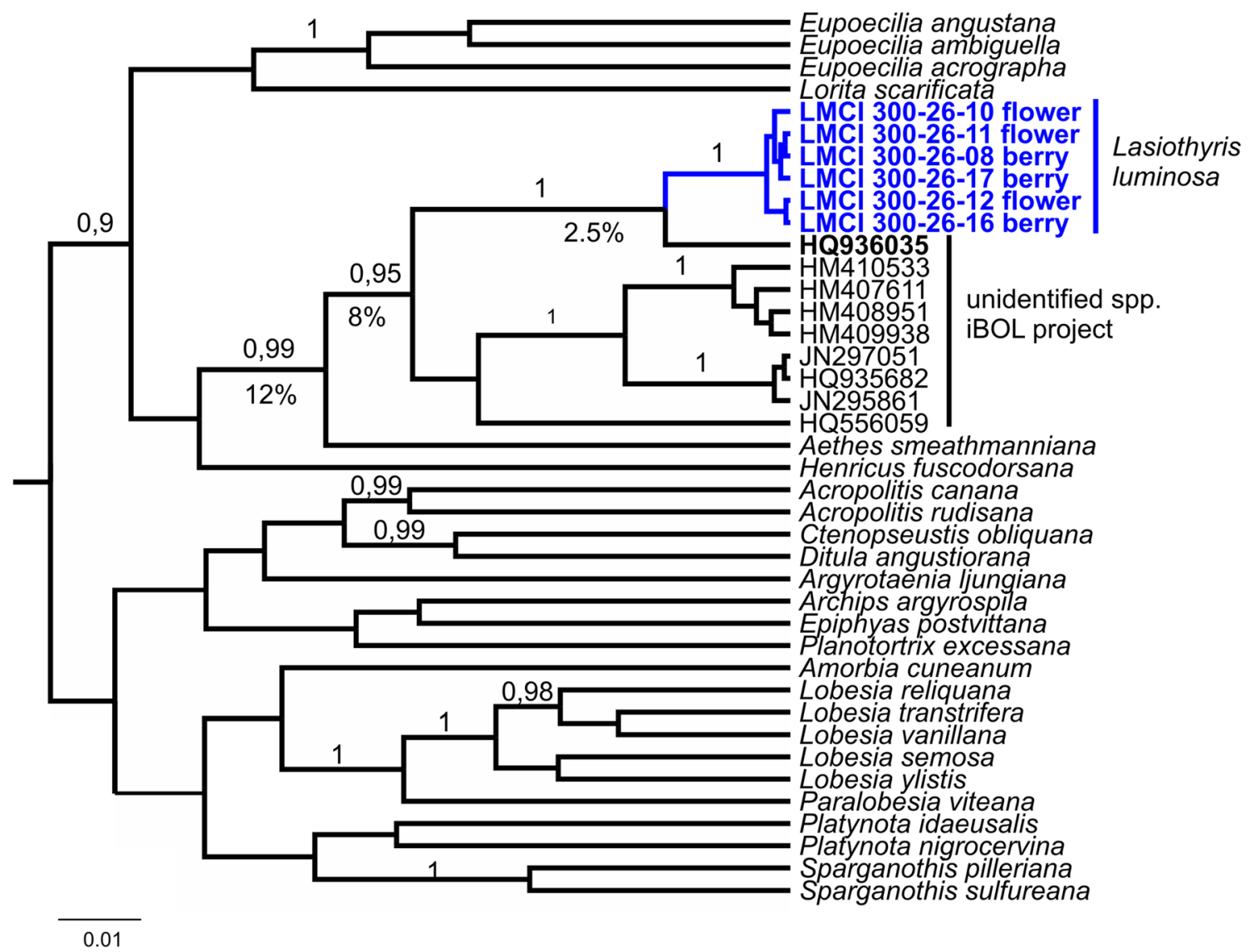

Fig 2 Bayesian consensus tree of Lasiothyris luminosa based on 658 base pairs (bp) of the mitochondrial gene cytochrome oxidase I, including a wide range of tortricid lineages, constructed in order to establish the monophyletic status of specimens from northeastern Brazil. 
Fig 3 Damage to grapes caused by larvae of Lasiothyris luminosa. A Tangled flower portions (circled area) resulting from general feeding on inflorescence. B Internal feeding on flower bud, as indicated by a circular entrance on the surface, clogged with feces (indicated by arrow). C Flower pistil, with the anterior portion of a first larval instar protruding from the feeding entrance. D External attachment between berries (inside rectangle), resulting from double feeding in contiguous berries. E General aspect of internal damage in a cross-sectioned berry. F Late-instar larva while internally crossing contiguous berries, shown by detaching the area marked in $\mathbf{D}$ (arrow indicates entrance located on the upper berry). Scale bars $=4,1,1$, 10,10 , and $4 \mathrm{~mm}$, respectively.

region (Bovey 1966, Roehrich \& Boller 1991) and has been recently introduced in California (USA) (Varela et al 2010), Chile, and Argentina (Gonzalez 2010). Considering the similarity to $L$. botrana, we suggest the use of the common name, American grapevine moth, for L. Iuminosa.

Acknowledgments We are grateful to Thales R. O. Freitas (UFRGS) for the laboratory facilities used in the molecular analyses, and to Vitor $\mathrm{O}$. Becker (Reserva Serra Bonita) for confirming the identity of the species. We benefited from taxonomic comments by John W. Brown (Smithsonian Institution) on other, closely allied Neotropical Cochylini moths, and he also allowed us to access barcode data in the BOLD System Tortricidae projects. Thanks are also due to Denis S. Silva for editing the plates, and to Janet W. Reid for editing the text. G.L. Gonçalves was supported by a Postdoctoral CAPES Fellowship (PNPD), and G.R.P. Moreira by a grant from CNPq (project number 309853/ 2014-1).

Electronic supplementary material The online version of this article (doi:10.1007/s13744-016-0379-9) contains supplementary material, which is available to authorized users.

\section{References}

Bovey P (1966) Superfamille des Tortricidae-L'Eudemis de la vigne. Entomol Appl Agric 2:859-887

Bustamante PMAC (2009) A fruticultura no Brasil e no Vale do São Francisco: Vantagens e desafios. Revta Econôm Nordeste 1: 153-171. $<$ http://www.bnb.gov.br/projwebren/Exec/artigoRenPDF.aspx?cd_ artigo_ren=1120>.

Gilligan TM, Baixeras J, Brown JW, Tuck KR (2014) T@RTS: Online world catalogue of the Tortricidae (Ver. 3.0). Available at: http://www. tortricid.net/catalogue.asp [Accessed on 28 Dec 2015]

Gonzalez M (2010) Lobesia botrana: polilla de la uva. Rev Enol 2:2-5

Razowski J, Becker VO (1983) Brazilian Cochylidii (Lepidoptera, Tortricidae). Acta Zool Cracov 26:421-464

Razowski J, Becker VO (1993) Revision of the cochyline genus Lasiothyris Meyrick (Lepidoptera, Tortricidae), with a description of 8 new species. Acta Zool Cracov 36:121-136

Regier J, Brown JW, Mitter C, Baixeras J, Cho S, Cummings MP, Zwick A (2012) Phylogeny of the leaf-roller moths (Lepidoptera: Tortricidae) and its implications for classification and life history evolution. PLoS ONE 19:2012. doi:10.1371/journal.pone.0035574

Roehrich R, Boller E (1991) Tortricids in vineyards. In: Van der Geest LPS, Evenhuis $\mathrm{HH}$ (eds) Tortricid pests: their biology, natural enemies and control. Elsevier, Amsterdam, pp 507-514

Varela LG, Smith RJ, Cooper ML, Hoenisch RW (2010) First report of European grapevine moth, Lobesia botrana, in Napa Valley vineyards. Pract Wine Vineyard J 2:1-5 